nappy was being changed; there was a "crack," and he was distressed.

In our view it is unwise to label these fractures as spontaneous, although the force required may be less than that needed to fracture well mineralised bones. A difficulty arises if a non-accidental injury has occurred: if the fracture has been accepted as spontaneous the child is left unprotected. Children with disability are at greater risk of abuse than their peers, and some of these fractures will be the result of abuse. ${ }^{23}$ Have Lingam and Joester considered why the school attended by the subjects of their reports apparently has such a high incidence of fracture of the femur?

CHRISTOPHER J HOBBS Consultant community paediatrician JANE $M$ WYNNE

Community Child Health, Consultant community paediatrician Leeds LS2 9NP

1 Lingam S, Joester J. Spontaneous fractures in children and adolescents with cerebral palsy. $B M 7$ 1994;309:265.

2 Ammerman RT, Van Hasselt V, Hersen M. 1988 Abuse and neglect in handicapped children: a critical review of family violence. Fournal of Family Violence 1988;3:53-72.

3 Hobbs CJ, Hanks HGI, Wynne JM. Child abuse and neglec. Edinburgh: Churchill Livingstone, 1993.

\section{Bone marrow transplantation}

\section{Review articles must accurately reflect current practice}

EDITOR,-Richard L Soutar and Derek J King succinctly review a complex, multidisciplinary, and rapidly changing clinical topic-bone marrow transplantation-but there are some errors and omissions.' The authors correctly cite cytomegalovirus as a major problem after bone marrow transplantation but fail to mention that early use of ganciclovir has virtually eliminated mortality related to cytomegalovirus infection in patients who have received allografts from siblings. Cytomegalovirus infection commonly presents as an interstitial pneumonitis, and to state that "treatment is supportive" in this syndrome is misleading.

As this article is intended for a general medical readership it should distinguish between the indications for and the complications and outcome of transplantation of autologous grafts, matched grafts from siblings, and matched grafts from unrelated donors. The failure to define these differences is a recurrent problem throughout the article. For instance, box 1 outlines the disorders suitable for transplantation but fails to discriminate which is best treated by which procedure. Myeloma is excluded from the list even though the Medical Research Council's current myeloma VII trial includes autologous grafts.

The number of bone marrow transplant procedures performed in Britain will undoubtedly increase appreciably in the future. Thus review articles must accurately reflect current practice, particularly if they might be used as information for patients. Perhaps this would be more likely to be achieved if units that specialise in bone marrow transplantation helped to write such articles.

SIMON A J RULE Senior registrar STEPHEN G O'BRIEN Research fellow ANDREW SPENCER Research fellow

JANE APPERLEY Senior lecture JOHN M GOLDMAN

LRF Leukaemia Unit,

Professor

Royal Postgraduate Medical School,

Hammersmith Hospital,

London W12 0NN

1 Soutar RL, King DJ. Bone marrow transplantation. $B M \mathcal{f}$ 1995;310:31-6. (7 January.)

\section{Extent of transplantation in Britain is} overrepresented

EDITOR,-Richard L Soutar and Derek J King may have misled purchasers and providers of health care by overrepresenting the extent of bone marrow transplantation in Britain. ${ }^{1}$ The data in their figure 1 refer to results recorded by the International Bone Marrow Transplant Registry worldwide during the 1980 s, not just in Britain, ${ }^{2}$ and are therefore both out of date and irrelevant. Information from the international marrow unrelated search and transplant study suggests that around 550 allogeneic transplant operations (with transplants from healthy donors) were performed annually in Britain during 1989-93. ${ }^{3}$ Unfortunately, no accurate records exist for autografts, and a national register is urgently needed for audit. The records from international registries for Britain remain inaccurate because of underreporting of bone marrow transplantation.

The authors open with the statement that bone marrow transplantation developed rapidly from experimental to established treatment. Development was certainly not rapid, and for most disorders bone marrow transplantation is used only in clinical trials. This can be illustrated by the fact that, after the first successful operation transplanting a graft from an identical twin in 1956, all 200 bone marrow transplant operations reported in the literature up to 1968 were unsuccessful. These early allogeneic transplant operations yielded catastrophic results because of marrow rejection and graft versus host disease. It was the dogged persistence of Thomas and others through the 1960 s and 1970s in a field that most investigators abandoned that led to modest success. Thomas's contribution was recognised in the award of the Nobel prize for medicine in 1990.

Other inaccuracies concern us. Bone marrow transplantation would certainly not be considered for all patients with acute myeloid leukaemia, and in the case of sickle cell disease it is highly contentious. Nine months between transplantation and return to work would be unusually long. This overdetailed review is likely to confuse in certain fundamental aspects of bone marrow transplantation, and we would refer interested and concerned readers to Barrett and Treleaven's book. ${ }^{+}$

\section{GLENN RAINEY}

Senior registrar

Department of Haematology,

Southmead Hospital NHS Trust,

Bristol BS10 5NB

Department of Transplantation Science,

JILL M HOWS University of Bristol

Brisol

Senior lecturer

1 Soutar RL, King DJ. Bone marrow transplantation. $B M \mathcal{F}$ 1995;310:31-6. (7 January.)

2 Rowlings PA, Horowitz MM, Rimm AA, Sobocinski MJ, Zhang MJ, Bortin MM. Report from the International Bone Marrow Transplant Registry. In: Terasaki PI, Cecka JM, eds. Clinical transplants 1992. Los Angeles: UCLA Tissue Typing Laboratory, 1992:83-90.

3 Downie T, Hows JM, Gore SM, Bradley BA, Howard MR. A survey of the use of unrelated donor bone marrow transplantation at 46 centres worldwide. Bone Marrow Transplantation (in press).

4 Treleaven J, Barrett J, eds. Bone marrow transplantation in practice. Edinburgh: Churchill Livingstone, 1992.

\section{Comparative data on quality of care and outcome are urgently needed}

EDrToR,-Bone marrow transplantation has a high profile in health care. Restricted access was the catalyst for the priority setting exercise in Oregon, and there is controversy about American insurers' liability to cover new technology of unproved benefit. Richard L Soutar and Derek J King's review of bone marrow transplantation'-or, in recognition of alternative sources of stem cells, ${ }^{12}$ transplantation of haemopoietic stem cells-is educational; debate on important issues of access, appropriateness, and quality of care continues.

Access to transplantation of allogeneic haemopoietic stem cells varies internationally; there was a twofold difference in rates between the country with the highest (France, 1.34/100000) and lowest (Germany, 0.56/100000) rate among 10 countries studied. ${ }^{3}$ Interestingly, the procedure was performed as commonly in Britain $(0 \cdot 82 / 100000)$ as in the United States $(0 \cdot 81 / 100000) .^{3}$

Demand for transplantation of autologous haemopoietic stem cells is expected to increase rapidly with extension of the upper age limit to 70 or more ${ }^{2}$ and the increasing use of high dose chemotherapy to treat common cancers. A recent international consensus panel noted, however, "Although HDC [high dose chemotherapy] and HSC [haemopoietic stem cell] transplantation has a good theoretical basis, it has not been established as superior to conventional therapy for any stage of any adult solid tumor." Nevertheless, Soutar and King list several cancers as suitable candidates.

The consensus panel also gave clear guidance on the appropriateness of transplantation of haemopoietic stem cells and identified areas in which randomised trials are most urgently needed to resolve clinical uncertainty. ${ }^{+}$Professional and public assumptions about the effectiveness of transplanation of haemopoietic stem cells in acute myeloid leukaemia are apparently limiting recruitment to a trial conducted by the Medical Research Council. ${ }^{1}$ Prejudgment of this issue could reduce accrual to other trials, which, given the relative rarity of the clinical situations prioritised by the consensus panel, will need to be national, if not multinational. ${ }^{45}$

High dose chemotherapy and transplantation of haemopoietic stem cells generally require extracontractual referral. Approval for such referrals might depend on treatment being delivered in the context of agreed, randomised trials of high dose chemotherapy versus conventional treatment when evidence of superior outcome is lacking. Even in the United States there is some professional support for this view.'

The Expert Advisory Group on Cancer recommends that intensive treatment and transplantation of haemopoietic stem cells should be restricted to cancer centres. But many district general hospitals currently undertake such treatment, and market forces are likely to encouarge further dissemination. Comparative data on quality of care and outcome are urgently needed so that health care commissioners can make rational decisions regarding support for developments in services.

MAGGIE HARDING

Health Care Evaluation Unit, Senior registrar in public health medicine

Department of Public Health Sciences,

St George's Hospital Medical School,

London SW 17 ORE

1 Soutar RL, King DJ. Bone marrow transplantation. BMF 1995;310:31-6. (7 January.)

2 Holyoake TL, Franklin IM. Bone marrow transplants from peripheral blood. $B M \mathcal{f} 1994 ; 309: 4-5$

3 Silberman G, Crosse MG, Peterson EA, Weston RC, Horowitz MM, Appelbaum FR, et al. Availability and appropriateness of MM, Appelbaum FR, et al. Availability and appropriateness of allogeneic bone marrow transplantation for chronic myed
leukemia in 10 countries. NEngl F Med 1994;331:1063-7.

4 Coiffier B, Philip T, Burnett AK, Symann ML. Consensus conference on intensive chemotherapy plus hematopoietic stem-cell transplantation in malignancies: Lyon, France, Jun 4-6, 1993. F Clin Oncol 1994;12:226-31.

5 Canellos GP. High-dose therapy: here to stay or just visiting? $f$ Clin Oncol 1994;12:5-6.

\section{Authors' reply}

EDITOR,-Our article was designed for a general readership, primarily general practitioners, rather than fellow haematologists. It was an attempt to cover a large, complex, and expanding subject in a manner that would be comprehensible and educational to medical staff who do not work 